\title{
Sosialisasi Kesehatan dalam Pencegahan Penyebaran COVID-19 di Desa Gontar Baru Kecamatan Alas Barat Kabupaten Sumbawa
}

\author{
Nur Arifatus Sholihah \\ Sekolah Tinggi Ilmu Kesehatan Griya Husada Sumbawa, Jl. Lingkar Kebayan, Sumbawa Besar. \\ Email: arifatus93@gmail.com
}

(Diajukan: 10 Agustus 2021, Direvisi: 25 Oktober 2021, Diterima: 25 Oktober 2021)

\begin{abstract}
ABSTRAK
Pandemi COVID-19 saat ini telah menarik perhatian besar dari masyarakat. Terutama bagi mereka yang kurang dalam penerimaan dan pemahaman informasi terkait COVID-19. Pemerintah telah mencanangkan rencana penanganan penyebaran COVID-19, dan untuk itu menghimbau kepada masyarakat untuk memahami penyebaran COVID-19 melalui berbagai metode pelaksanaan yang harus dilaksanakan sesuai dengan protokol kesehatan. Protokol kesehatan yang dimaksud adalah menggunakan pola hidup sehat dan perilaku hidup bersih, memakai masker untuk mengukur suhu tubuh (deteksi), menjaga jarak aman (physical distance), menghindari keramaian, mengubah kebiasaan fisik seperti berjabat tangan, dan mencuci tangan. sering dengan sabun. (Hand sanitizer), sering menyemprotkan desinfektan, memperhatikan label batuk, mengisolasi diri, namun masih ada saja masyarakat yang tidak mengerti atau bahkan mengabaikan atau acuh terhadap diri sendiri dan orang lain. Tujuan kegiatan pengabdian kepada masyarakat ini adalah sosialisasi kesehatan pencegahan penyebaran COVID-19 di Desa Gontar Kecamatan Alas Barat Kabupaten Sumbawa. Metode yang digunakan dalam pengabdian masyarakat di Desa Gontar Baru Kecamapatan Alas Barat, Kabupaten Sumbawa ini adalah melalui ceramah pengenalan dan pembahasan materi COVID-19. Pengabdian di lakukan di D di Desa Gontar Baru Kecamapatan Alas Barat, Kabupaten Sumbawa pada tanggal 12 Juni 2021 dengan melibatkan seluruh pejabat dan perwakilan masyarakat. Hasil evaluasi menunjukkan bahwa tingkat pengetahuan dan pemahaman masyarakat masih rendah terkait dengan pencegahan dalam penyebaran COVID-19 sebesar 33,3\% di kategori sedang dan $26,7 \%$ di kategori kurang. Kegiatan pengabdian ini dapat membantu masyarakat untuk meningkatkan kesadaran berupa kesadaran diri untuk mencegah penyebaran COVID-19.
\end{abstract}

Kata kunci : Sosialisasi, COVID-19, Protokol kesehatan.

\begin{abstract}
The current COVID-19 pandemic has attracted great attention from the public. Especially for those who are lacking in receiving and understanding information related to COVID-19. The government has launched a plan to deal with the spread of COVID-19, and for that appeals to the public to understand the spread of COVID19 through various implementation methods that must be carried out in accordance with health protocols. The health protocol in question is using a healthy lifestyle and clean living behavior, wearing a mask to measure body temperature (detection), maintaining a safe distance (physical distance), avoiding crowds, changing physical habits such as shaking hands, and washing hands. often with soap. (Hand sanitizer), often spray disinfectant, pay attention to cough labels, isolate themselves, but there are still people who don't understand or even ignore or ignore themselves and others. The purpose of this community service activity is to disseminate health to prevent the spread of COVID-19 in Gontar Village, West Alas District, Sumbawa Regency. The method used in community service in Gontar Baru Village, Alas Barat District, Sumbawa Regency is through introduction lectures and discussion of COVID-19 material. The service was carried out at D in Gontar Baru Village, West Alas District, Sumbawa Regency on June 12, 2021, involving all officials and community representatives. The evaluation results show that the level of knowledge and understanding of the community is still low related to prevention in the spread of COVID-19 by $33.3 \%$ in the medium category and
\end{abstract}


$26.7 \%$ in the less category. This service activity can help the community to increase awareness in the form of self-awareness to prevent the spread of COVID-19.

Keywords: Socialization, COVID-19, Health protocol.

\section{PENDAHULUAN}

WHO menyatakan 2019-nCoV sebagai PHEIC (Public Health Emergency Of International concern) pada tanggal 30 Januari 2020. Ini adalah keenam kalinya WHO mengumumkan PHEIC sejak International Health Regulations (IHR) mulai berlaku pada 2005, setelah kasus SARS-CoV dan MERS-CoV yang memiliki pengaruh berskala besar dan patogen tehadap populasi manusia. Pada tanggal 11 maret 2020, WHO sangat prihatin dengan tingkat penyebaran dan keparahan yang mengkhawatirkan, WHO membuat keputusan bahwa COVID-19 dapat dikategorikan sebagai pandemi (WHO, 2020). Munculnya virus corona terhadap manusia, yaitu MERS-CoV dan SARS-CoV, diperkirakan didorong oleh keunggulan virus tersebut yang diadaptasi oleh kelelawar menjadi inang perantara. Untuk SARS-CoV, inang perantara ini diyakini merupakan musang palem, sementara unta memainkan peran itu untuk MERS-CoV. Analisis genetik SARS-CoV-2 menunjukkan bahwa virus tersebut kemungkinan berasal dari reservoir kelelawar.Ada sejumlah teori tentang keberadaan inang hewan perantara untuk asal-usul SARS-CoV-2, tetapi bukti tersebut tidak dapat disimpulkan.

Di masa pandemi ini, masyarakat harus mengikuti prosedur kebersihan untuk mencegah penyebaran COVID-19. Protokol kesehatan yang dimaksud adalah menerapkan pola hidup sehat dan perilaku hidup bersih, memakai masker untuk mengukur suhu tubuh (sensing), menjaga jarak aman (physical distance), menghindari keramaian, mengubah kebiasaan yang berhubungan dengan tubuh, seperti berjabat tangan, menggunakan sabun, sering mencuci tangan. Hand sanitizer), sering semprot desinfektan, perhatikan label batuk, dan isolasi mandiri (Sutrayanti, 2020).

Meski pemerintah telah menerapkan protokol kesehatan, kasus COVID-19 semakin meningkat setiap harinya dan tingkat penularannya cukup tinggi. Kementerian Kesehatan (2020) menyatakan bahwa peningkatan kasus harian menunjukkan bahwa kepatuhan masyarakat terhadap protokol kesehatan masih rendah (belum optimal) (Kementerian Kesehatan Republik Indonesia, 2020a).

Kurangnya kedisiplinan masyarakat untuk mematuhi protokoler kesehatan dapat dilihat dari beberapa faktor, antara lain faktor pendidikan berupa pemahaman masyarakat yang kurang memadai, meremehkan COVID-19. Faktor kepercayaan termasuk percaya pada 
takdir tanpa berusaha menjaga diri sendiri atau tetap sehat. Faktor ekonomi yang mengakibatkan harus bekerja tanpa mempertimbangkan perjanjian kesehatan. Hilangnya kepercayaan terhadap kebijakan pemerintah, lemahnya perangkat hukum, atau kurangnya ketegasan pemerintah untuk menjatuhkan sanksi kepada pihak yang tidak mematuhi perjanjian kesehatan (Sutrayanti, 2020).

Pengabdian kepada masyarakat bertema sosialisasi sehat pencegahan COVID-19 di di Desa Gontar Baru Kecamapatan Alas Barat, Kabupaten Sumbawa. Investigasi dan observasi menunjukkan bahwa sebagian besar masyarakat di Desa Gontar Baru, Kecamatan Alas Barat belum paham untuk mencegah penyebaran COVID-19. Hasil wawancara dengan masyarakat mengungkapkan tidak mungkin memperoleh informasi mengenai masalah kesehatan terkait pencegahan penyebaran COVID-19. Berdasarkan hal tersebut, penulis tertarik untuk mengembangkan pengabdian masyarakat yang melibatkan mahasiswa terkait sosialisasi kesehatan untuk meningkatkan kesadaran masyarakat dalam pencegahan penyebaran COVID-19.

\section{METODE}

Kegiatan pengabdian masyarakat ini dilakukan dengan metode ceramah dan diskusi kepada seluruh peserta yang hadir. Keseluruhan jumlah peserta yang hadir di lokasi ini berjumlah 30 orang. Sosialisasi dilakukan pada hari Sabtu, 12 Juni 2021, di mulai pukul 08:30 hingga 12:00 WITA. Proses penyuluhan dilakukan dengan mengumpulkan masyarakat di Aula kantor desa. Tim pelaksana dan mahasiswa melakukan sosialisasi dan pembagian paket makanan sehat serta pembagian masker. Sistem penyuluhan dilakukan dengan sistem diskusi dan bincang-bincang. Hal ini ditujukan untuk mengefektifkan proses sosialisasi. Bagan tahapan pelaksanaan pengabdian masyarakat dapat dilihat pada Gambar 1.

\begin{tabular}{|l|l|l|}
\hline \multicolumn{1}{|c|}{ Tahap Persiapan } \\
1. Survei lokasi dan \\
Koordinasi dengan \\
Kelurahan Desa \\
Gontar Baru
\end{tabular}

Gambar 1. Bagan Kegiatan Pengabdian Masyarakat Desa Gontar Baru Kecamatan Alas Barat Kabupaten Sumbawa 
Keterangan Gambar 1. Bagan Tahapan metode yang dilakukan adalah :

1. Survei Lokasi dan Koordinasi dengan Kelurahan

Survei dilakuan bersama dengan team mahasiswa untuk mengetahui lokasi tempat pelaksanaan pengadian dan melakukan koordinasi langsung dengan pihak Desa Gontar Baru setempat. Survei lokasi dilakukan pada hari Kamis, 10 Juni 2021.

2. Pengantaran Surat

Setelah dilakukan koordinasi langsung melalui via telfon maka kami bersedia bekerjasama dalam melaksanakan pengabdian masyarakat di Desa Gontar Baru Kecamatan Alas Barat Kabupaten Sumbawa dengan mengirimkan surat koordinasi waktu pelaksanaan pengabdian yang nanatinya suarat tersebut akan diteruskan kepada masyarakat yang menjadi peserta dalam pelaksanaan pengadian masyarakat.

3. Persiapan Aula Kantor Desa

Persiapan yang dilakukan adalah tempat pelaksanaan yang diadakan di Aula Kantor Desa Gontar Baru Kecamatan Alas Barat Kabupaten Sumbawa yang dilaksanakan pada hari Sabtu, 12 Juni 2021, di mulai pukul 08:30 hingga 12:00 WITA dengan 30 peserta yang hadir.

4. Ceramah

Metode ceramah digunakan untuk menyampaikan materi dengan rinci. Topik yang disampaikan antara lain pentingnya mecegah penyebaran COVID-19 dengan mematuhi protokoler kesehatan yaitu menggunakan pola hidup sehat dan perilaku hidup bersih, memakai masker untuk mengukur suhu tubuh (deteksi), menjaga jarak aman (physical distance), menghindari keramaian, mengubah kebiasaan fisik seperti berjabat tangan, dan mencuci tangan. sering dengan sabun. (Hand sanitizer), sering menyemprotkan desinfektan, memperhatikan label batuk, mengisolasi diri.

5. Diskusi

Metode diskusi digunakan untuk mengakomodir pertanyaan dan masukan dari materi yang disampaikan.

6. Evaluasi

Kegiatan ini dilakukan untuk mengetahui tingkat pemahaman peserta kegiatan pengabdian terhadap materi dan praktik yang telah dilakukan dengan cara menanyakan 10 item pertanyaan sebelum diberikan sosialisasi sebagai bentuk pengetahuan awal para peserta lalu setelah itu diberikan sosialisasi dan penyuluhan kemudian kembali diberikan 10 item pertanyaan dalam bentuk kuesioner. 


\section{HASIL, PEMBAHASAN, DAN DAMPAK}

Proses penyuluhan yang dilakukan yaitu Survei dilakuan bersama dengan team mahasiswa untuk mengetahui lokasi tempat pelaksanaan pengadian dan melakukan koordinasi langsung dengan pihak Desa Gontar Baru setempat. Survei lokasi dilakukan pada hari Kamis, 10 Juni 2021. Setelah dilakukan koordinasi langsung melalui via telfon maka kami bersedia bekerjasama dalam melaksanakan pengabdian masyarakat di Desa Gontar Baru Kecamatan Alas Barat Kabupaten Sumbawa dengan mengirimkan surat koordinasi waktu pelaksanaan pengabdian yang nanatinya suarat tersebut akan diteruskan kepada masyarakat yang menjadi peserta dalam pelaksanaan pengadian masyarakat. Persiapan yang dilakukan adalah tempat pelaksanaan yang diadakan di Aula Kantor Desa Gontar Baru Kecamatan Alas Barat Kabupaten Sumbawa yang dilaksanakan pada hari Sabtu, 12 Juni 2021, di mulai pukul 08:30 hingga 12:00 WITA dengan 30 peserta yang hadir. Tim pelaksana dan mahasiswa melakukan sosialisasi dan pembagian paket makanan sehat serta pembagian masker. Sistem penyuluhan dilakukan dengan sistem diskusi dan bincang-bincang. Metode ceramah digunakan untuk menyampaikan materi dengan rinci. Topik yang disampaikan antara lain pentingnya mecegah penyebaran COVID-19 dengan mematuhi protokoler kesehatan yaitu menggunakan pola hidup sehat dan perilaku hidup bersih, memakai masker untuk mengukur suhu tubuh (deteksi), menjaga jarak aman (physical distance), menghindari keramaian, mengubah kebiasaan fisik seperti berjabat tangan, dan mencuci tangan. sering dengan sabun. (Hand sanitizer), sering menyemprotkan desinfektan, memperhatikan label batuk, mengisolasi diri. Metode diskusi digunakan untuk mengakomodir pertanyaan dan masukan dari materi yang disampaikan. Kegiatan ini dilakukan untuk mengetahui tingkat pemahaman peserta kegiatan pengabdian terhadap materi dan praktik yang telah dilakukan dengan cara menanyakan 10 item pertanyaan sebelum diberikan sosialisasi sebagai bentuk pengetahuan awal para peserta lalu setelah itu diberikan sosialisasi dan penyuluhan, kemudian kembali diberikan 10 item pertanyaan dalam bentuk kuesioner. Hal ini ditujukan untuk mengefektifkan proses sosialisasi, hasil pengukuran tingkat pengetahuan dapat dilihat pada Tabel 1.

Tabel 1. Hasil Pengetahuan Sebelum Pengabdian Masyarakat

\begin{tabular}{cc}
\hline Kategori Pengetahuan & Persentase \\
\hline Baik & $20 \%$ \\
Cukup & $30 \%$ \\
Kurang & $50 \%$ \\
\hline
\end{tabular}

(Sumber: Data Primer yang diolah, 2021) 
Hasil Tabel 1. menunjukkan bahwa Setelah diberikan perlakuan dalam sosialisasi dan diberikan penjelasan mendetail, maka sebagai bahan evaluasi, para peserta diberikan pertanyaan kembali dengan hasil presentase pengetahuan yang cukup meningkat. Meskipun tetap belum ada yang masuk dalam kategori baik (jawaban benar di atas 50\%) akan tetapi terlihat peningkatan pada level kategori cukup seperti yang terlihat pada Tabel 2 .

Tabel 2. Hasil Pengetahuan Setelah Pengabdian Masyarakat

\begin{tabular}{cc}
\hline Kategori Pengetahuan & Persentase \\
\hline Baik & $40 \%$ \\
Cukup & $33.3 \%$ \\
Kurang & $26,7 \%$ \\
\hline
\end{tabular}

(Sumber: Data Primer yang diolah, 2021)

Hasil Tabel 2. menunjukan bahwa pengetahuan masyarakat harus lebih ditingkatkan serta peningkatan kemampuan masyarakat untuk menerima informasi secara cepat dan tepat dan menerapkan protokol kesehatan untuk mencegah penyebaran COVID-19, serta oleh berbagai faktor, seperti. Mengenai kurangnya edukasi untuk menerima informasi/informasi kesehatan.

\section{SIMPULAN}

Kegiatan pengabdian masyarakat ini menekankan pada pentingnya menjaga diri yaitu dengan berbagai metode pelaksanaan yang harus dilaksanakan sesuai dengan protokol kesehatan. Protokol kesehatan yang dimaksud adalah menggunakan pola hidup sehat dan perilaku hidup bersih, memakai masker untuk mengukur suhu tubuh (deteksi), menjaga jarak aman (physical distance), menghindari keramaian, mengubah kebiasaan fisik seperti berjabat tangan, dan mencuci tangan. sering dengan sabun. (Hand sanitizer), sering menyemprotkan desinfektan, memperhatikan label batuk, mengisolasi diri.

Hasil evaluasi menunjukkan bahwa tingkat pengetahuan dan pemahaman masyarakat masih rendah terkait dengan pencegahan dalam penyebaran COVID-19 sebesar 33,3\% di kategori sedang dan 26,7\% di kategori kurang. Kegiatan pengabdian ini dapat membantu masyarakat untuk meningkatkan kesadaran berupa kesadaran diri untuk mencegah penyebaran COVID-19.

\section{UCAPAN TERIMAKASIH}

Ucapan Terimakasih ini disampaikan kepada seluruh pihak terkait dengan kegiatan pengabdian masyarakat, baik kepada masyarakat Desa Gontar Kecamatan Alas Barat 
Kabupaten Sumbawa, kepada mahasiswa yang terlibat, serta tak lupa kepada Suami tercinta Mas Dian Bagus Candra usuma, S.Kom yang senantiasa ikut serta mendampingi penulias dalam setiap kegiatan.

\section{DAFTAR PUSTAKA}

Hasibuan, R., \& Ashari, A. (2020). Optimasi Peran Negara Menghadapi Pandemi Corona Virus Disease 2019 dalam Perspektif Hukum Tata Negara Darurat. SALAM: Jurnal Sosial dan Budaya Syar-i, 7(7), 581-594. doi: $\underline{10.15408 / \text { sjsbs.v7i7.15379 }}$

Health Line. 2020. 9 Upaya Pencegahan Penularan Corona COVID-19 https://www.liputan6.com/otomotif/read/4212220/9-upaya-pencegahan-penularancorona-COVID-19

Protokol, F. F. K. P., \& Kasiyan, P. M. D. D. Program Studi S1 Keperawatan Fakultas Ilmu Kesehatan Universitas Muhammadiyah Jember

Ramadhan Tosepu, Joko Gunawan, Devi Savitri Effendy, La Ode Ali Imran Ahmad, Hariati Lestari, Hartati Bahar, Pitrah Asfian, Correlation between weather and Covid-19 pandemic in Jakarta, Indonesia, Science of The Total Environment, Volume 725, 2020 , 138436, ISSN 0048-9697, doi: 10.1016/j.scitotenv.2020.138436.

Sugiyono, 2011, Metode Penelitian Kuantitatif Kualitatif, Bandung, Alfabeta

Tobing, Samuel L. dkk, (2020). A Multidiciplinary Approach: Pelayanan Obsgin dalam Situasi Pandemi Covid 19. POGI Kalimantan Selatan, Program Studi Obstetri Ginekologi FK ULM. [online] Available at: [Accessed 31 April 2020]

World Health Organization (WHO), 2020, Coronavirus disease 2019 Situation Report 51 11th March 2020, World Health Organization, 2019(March), p. 2633. doi: 10.1001/jama.2020.2633.

Centers for Disease Control and Prevention, 2020, Coronavirus Disease 2019 (COVID19), [online] Available at: [Accessed 31 April 2020]. 